\title{
Analysis of Sheath and Core Structures of the Axial Filament of Treponema pallidum
}

\author{
By A. COCKAYNE, ${ }^{*}$ M. J. BAILEY AND C. W. PENN \\ Department of Microbiology, University of Birmingham, Birmingham BI5 2TT, UK
}

(Received 13 November 1986; revised 7 January 1987)

\begin{abstract}
Electron microscopy and SDS-PAGE have been used to analyse the polypeptide and antigenic composition of the sheath and core components of the axial filament of Treponema pallidum. The sheath contains a major $37 \mathrm{kDa}$ polypeptide which was solubilized by a combination of trypsin and urea treatments with concurrent loss of binding of anti-37 kDa monoclonal antibody. These studies also indicated some antigenic heterogeneity within the axial filament population. Trypsin treatment alone removed a number of antigenic determinants from the axial filament but left others intact, suggesting differences in their location within the sheath structure. A second $31.5 \mathrm{kDa}$ polypeptide may also be associated with the sheath. The axial filament core comprises at least two components, an antigenically dominant $33.5 \mathrm{kDa}$ polypeptide and a second of $34 \mathrm{kDa}$. The structure of the axial filament in $T$. pallidum and Treponema phagedenis biotype Reiterii was similar, but antigenic cross-reactivity of sheath and core components was incomplete.
\end{abstract}

\section{INTRODUCTION}

The axial filament of Treponema pallidum is a major antigenic component of the organism recognized early by the humoral immune system in infected animals (Penn et al., 1985). Axial filaments of $T$. pallidum and the cultivable non-pathogenic treponeme Treponema phagedenis are antigenically cross-reactive and the ready availability of large quantities of $T$. phagedenis axial filaments has allowed their assessment as antigens in diagnostic tests for syphilis (Strandberg Pedersen et al., 1982). The exact nature of the cross-reacting components on the different axial filaments is unknown. Morphological studies suggested that treponemal axial filaments were structurally complex (Hovind-Hougen, 1972, 1976, 1983), the axial filament core being surrounded by a sheath structure. This worker used various chemical treatments of $T$. phagedenis axial filaments to separate the core and sheath components although the polypeptides associated with these components and their antigenicity were not assessed. SDS-PAGE analysis of purified $T$. pallidum and $T$. phagedenis axial filaments (Bharrier \& Allis, 1974; Penn et al., 1985) emphasized their complexity with at least three polypeptides, representing a flagellin, analagous to those found in other bacterial flagella and one or more sheath-associated polypeptides, present in both species. We have tentatively identified a sheath-associated polypeptide of the $T$. pallidum axial filament (Bailey et al., 1987) and now, by a combination of chemical degradation of $T$. pallidum and by the use of monoclonal antibodies, we have been able to confirm the differentiation of the polypeptides associated with the core and sheath components and the extent of antigenic cross-reactivity of these structures in $T$. pallidum and $T$. phagedenis.

\section{METHODS}

Bacteria. T. pallidum was maintained in rabbits and harvested as described previously (Penn \& Rhodes, 1982), and was used after storage in extraction medium $+0 \cdot 1 \%$ sodium azide for $48 \mathrm{~h}$ at $4{ }^{\circ} \mathrm{C}$. Treponema phagedenis biotype Reiterii ( $T$. phagedenis) was grown at $37{ }^{\circ} \mathrm{C}$ in spirolate broth (Becton Dickinson) supplemented with $5 \%$

Abbreviation: hRSS, hyperimmune rabbit syphilitic serum. 
$(\mathrm{v} / \mathrm{v})$ newborn calf serum (Gibco). Bacteria were sedimented by centrifugation for $5 \mathrm{~min}$ at $11600 \mathrm{~g}$ and washed in phosphate buffered saline (PBS) $(0.01 \mathrm{M}$-sodium/potassium phosphate, $0.15 \mathrm{M}-\mathrm{NaCl}, \mathrm{pH} 7 \cdot 2)$ prior to use.

Purification of axial filaments from $T$. pallidum and $T$. phagedenis. Small quantities of axial filaments were prepared essentially as described by Penn et al. (1985), except that shearing of the filaments from the bacterial cell bodies was done in the presence of $0.2 \%(\mathrm{v} / \mathrm{v})$ Triton X-100 and preparations were treated twice with $0.2 \%(\mathrm{v} / \mathrm{v})$ Sarkosyl before sedimenting at $100000 \mathrm{~g}$ for $1 \mathrm{~h}$.

Chemical treatments of $T$. pallidum cells. To release axial filaments from beneath the treponemal outer membrane (Penn \& Rhodes, 1982), $1 \times 10^{8}$ bacteria were sedimented and incubated at $37^{\circ} \mathrm{C}$ for 30 min with $50 \mu 10 \cdot 2 \%(\mathrm{v} / \mathrm{v})$ Triton X-100 in $50 \mathrm{~mm}$-Tris/ $\mathrm{HCl}$ pH 8.2 and $150 \mu$ l PBS. Removal of the sheath from the axial filament was attempted by treatment with trypsin and/or urea essentially as described by Hovind-Hougen (1976). Treponemes $\left(1 \times 10^{8}\right)$ were incubated with $50 \mu \mathrm{l}$ Triton X-100 and either 6 or $50 \mu \mathrm{l}$ trypsin $\left(250 \mu \mathrm{g} \mathrm{ml}^{-1}\right.$ in PBS). The volume of the mixture was adjusted to $200 \mu \mathrm{l}$ with PBS and preparations were incubated at $37^{\circ} \mathrm{C}$ for $30 \mathrm{~min}$. Bacteria were then sedimented by centrifugation for $5 \mathrm{~min}$ at $11600 \mathrm{~g}$ and washed twice in distilled water. In some experiments treponemes treated with the lower concentration of trypsin were washed with water and then incubated with $100 \mu \mathrm{l}$ of different concentrations (1-6 M) of urea in water, or with water alone as control, at $37^{\circ} \mathrm{C}$ for $30 \mathrm{~min}$. The remaining material was then sedimented as described above and washed once in water.

SDS-PAGE and Western blotting. Polypeptides were separated on 8-20\% gradient polyacrylamide gels using the buffer system of Laemmli (1970) and were visualized by staining with $0.1 \%$ (w/v) PAGE Blue $83(\mathrm{BDH})$ in $10 \%$ $(\mathrm{v} / \mathrm{v})$ methanol, $7.5 \%(\mathrm{v} / \mathrm{v})$ acetic acid in water or by silver staining as described by Oakley $e$ t al., $(1980) ; 2 \times 10^{7}$ treponemes were loaded per lane. Molecular masses of polypeptides were calculated as described previously (Penn et al., 1985) using Bio-Rad (Watford) standards. For antigenic analysis polypeptides were transferred to a nitrocellulose membrane $(0.45 \mu \mathrm{m}$ pore size) as described by Towbin et al. (1979). After blocking of non-specific binding sites on the membrane by incubation for $1 \mathrm{~h}$ in $3 \%(w / v)$ BSA (Fraction V, Sigma) in PBS, blots were reacted with polyclonal (1/500 dilution) or monoclonal (1/50 dilution) antibodies in the same buffer containing $0.1 \%(\mathrm{w} / \mathrm{v}) \mathrm{BSA}$ and $0.1 \%(\mathrm{v} / \mathrm{v})$ Tween 20 for $2 \mathrm{~h}$ at room temperature. After washing in PBS, blots were incubated with horse radish peroxidase conjugated anti-mouse or anti-rabbit antibody (Miles Jeda) (1/2000 dilution) for $2 \mathrm{~h}$. After extensive washing, bound antibody was detected by reaction of blots with $0.03 \%(w / v) 4-c h l o r o-1$-naphthol and $0.13 \%(\mathrm{v} / \mathrm{v})$ hydrogen peroxide in $50 \mathrm{~mm}-\mathrm{Tris} / \mathrm{HCl}, \mathrm{pH} 7 \cdot 4$.

Electron microscopy. For morphological studies, treponemal preparations were resuspended in a minimum volume of PBS, transferred to Formvar-coated copper grids by floating the grids on drops of the bacterial suspension for $10 \mathrm{~min}$ at room temperature and stained as described below. For immunoelectron microscopy, preparations washed in PBS were resuspended in $1 \mathrm{ml}$ of hybridoma supernatant containing monoclonal antibody (approximate antibody concentration $\left.20 \mu \mathrm{g} \mathrm{m}^{-1}\right)$ or $1 \mathrm{ml}$ of polyclonal serum (1/100 dilution in PBS) and incubated at $37^{\circ} \mathrm{C}$ for $1 \mathrm{~h}$. After two washes in PBS bacteria were then transferred to grids. In some experiments antibody binding was visualized by staining directly after incubation with the primary antibody. Alternatively, non-specific binding sites on the grids were blocked by incubation on drops of $3 \%(\mathrm{w} / \mathrm{v})$ BSA for 10 min at room temperature, and antibody binding to the treponemes was detected by further incubation on drops of gold conjugated anti-mouse antibody (15 nm particle diameter, Polaron Watford) diluted $1 / 10$ in $20 \mathrm{~mm}-\mathrm{Tris} / \mathrm{HCl}$ $\mathrm{pH} 8 \cdot 2+0 \cdot 15 \mathrm{M}-\mathrm{NaCl}$ and $1 \%(\mathrm{w} / \mathrm{v}) \mathrm{BSA}$ for $45 \mathrm{~min}$ at $37^{\circ} \mathrm{C}$ in a humid atmosphere. Grids were then washed well in PBS, washed briefly in water and stained for $30 \mathrm{~s}$ with $3 \%(\mathrm{w} / \mathrm{v})$ sodium phosphotungstate $\mathrm{pH} 7.2$ in water before viewing in a Philips 201 electron microscope. Alternatively, grids were stained with ammonium molybdate by incubation on drops of $2 \%(\mathrm{w} / \mathrm{v}) \mathrm{KI}$ in water for $30 \mathrm{~s}$ followed by two drops of water, $10 \mathrm{~s}$ each, and $3 \%(\mathrm{w} / \mathrm{v})$ ammonium molybdate, $\mathrm{pH} 6 \cdot 5$, in water for $30 \mathrm{~s}$.

Antibody preparation. Anti-T. pallidum monoclonal antibodies were produced in this laboratory as described elsewhere (Bailey et al., 1987). Monoclonal antibodies CC9 and IB8, recognizing different antigenic determinants of the $37 \mathrm{kDa}$ axial filament polypeptide (Penn et al., 1985), and monoclonal antibody JD11, recognizing the $31.5 \mathrm{kDa}$ axial filament polypeptide, were used. Polyclonal mouse anti- $T$. pallidum antibodies to Triton/trypsin/6 M-urea-treated treponemes were prepared in female Balb/c mice. Mice were initially immunized intraperitoneally with $5 \times 10^{7}$ Triton/trypsin/urea-treated treponemes in Freund's complete adjuvant and subsequently after one and three weeks with a similar preparation in Freund's incomplete adjuvant. In addition, mice were immunized with a similar dose of antigen in PBS intravenously at the same times. Blood was collected one week after the final immunization. Polyclonal hyperimmune rabbit syphilitic serum (hRSS) was prepared as described previously (Penn \& Rhodes, 1982).

\section{RESULTS}

\section{Purification of axial filaments from $T$. pallidum and $T$. phagedenis}

Silver-stained SDS-PAGE profiles of $T$. pallidum and $T$. phagedenis and of axial filaments purified from these bacteria are shown in Fig. 1. T. pallidum axial filament preparations 


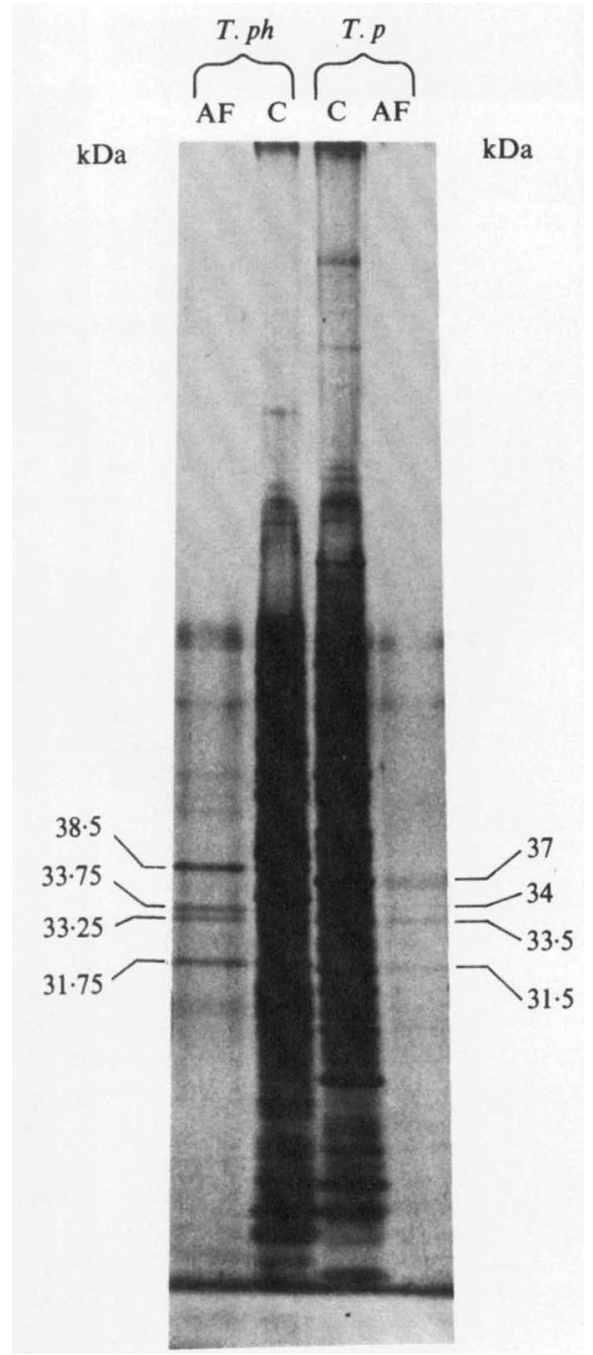

Fig. 1. Silver-stained SDS-PAGE of whole cells (C) and purified axial filaments (AF) of T. pallidum $(T . p)$ and $T$. phagedenis $(T . p h)$.

contained polypeptides of $37,34,33.5$ and $31.5 \mathrm{kDa}$. $T$. phagedenis axial filament preparations contained polypeptides of $38.5,33.75,33.25$ and $31.75 \mathrm{kDa}$. Variable quantities of other contaminating polypeptides were also occasionally detected in these preparations.

\section{Morphology of T. pallidum axial flaments and heterogeneity of antibody binding}

Ammonium molybdate staining of Triton-treated $T$. pallidum showed variations in the morphology of different axial filaments. The majority of filaments were sheathed, with a characteristic cross-hatched surface appearance (Fig. $2 a$ ). However, a small proportion of filaments in these preparations had lost all or part of their sheath structure. These axial filaments were markedly thinner than the sheathed filaments and differed significantly in surface appearance (Fig. 2a). Examination of similar preparations labelled with IgM monoclonal antibody $\mathrm{CC} 9$, specific for the $37 \mathrm{kDa}$ polypeptide, also indicated heterogeneity of antibody binding. A proportion of filaments failed to bind antibody, and reactivity along the length of individual filaments varied (Fig. $2 b$ ). Where antibody binding varied along the length of 

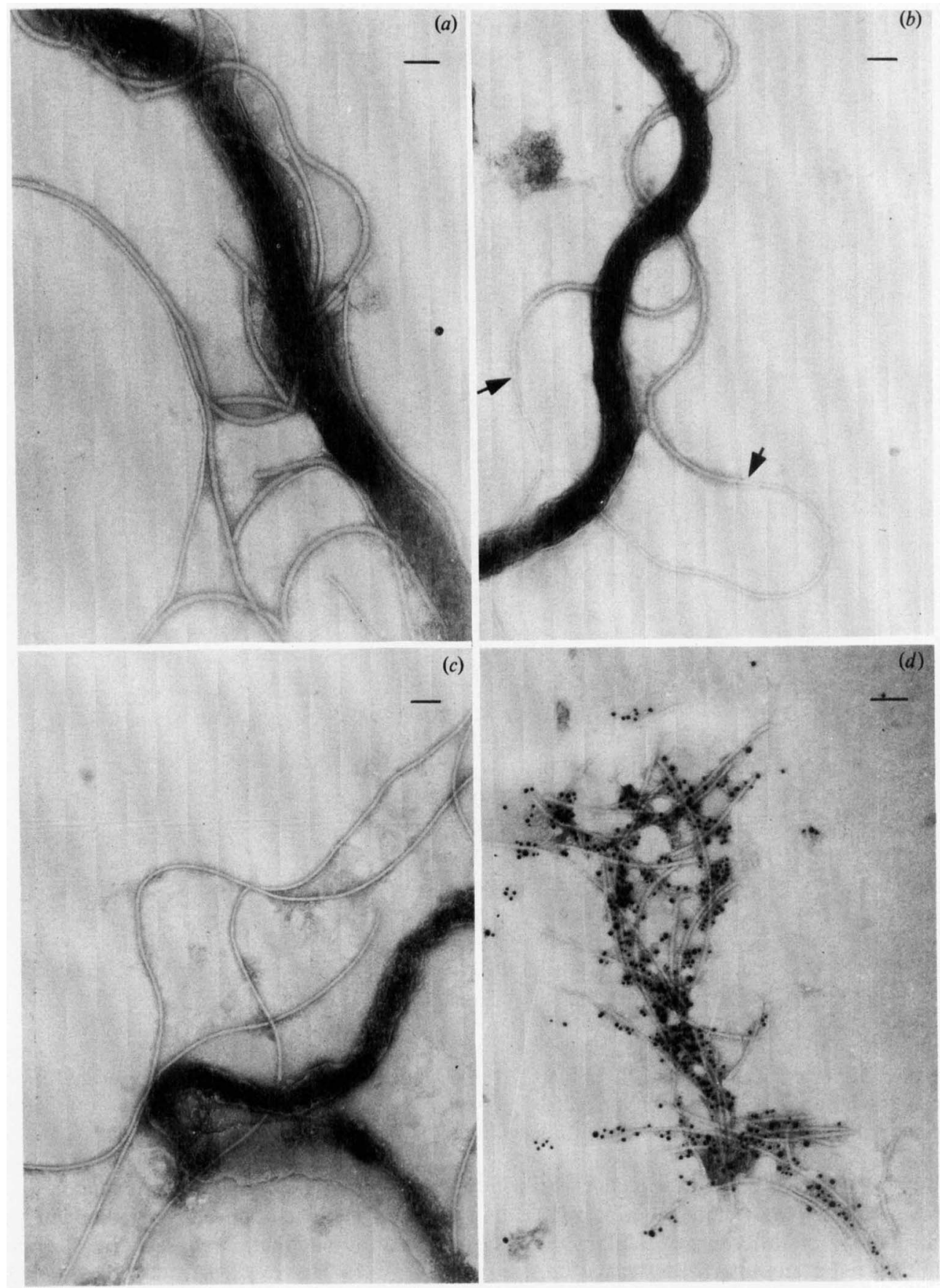

Fig. 2. Electron micrographs of molybdate-stained $T$. pallidum. (a) Triton treated; $(b)$ Triton-treated and reacted with monoclonal antibody $\mathrm{CC} 9$ (the arrows indicate the point at which sheath and antibody binding stops); (c) Triton/trypsin/6 M-urea-treated and reacted with CC9; $(d)$ as $(c)$ but reacted with mouse serum to urea-treated treponemes and then with anti-mouse gold conjugate. Bars, $0 \cdot 1 \mu \mathrm{m}$. 

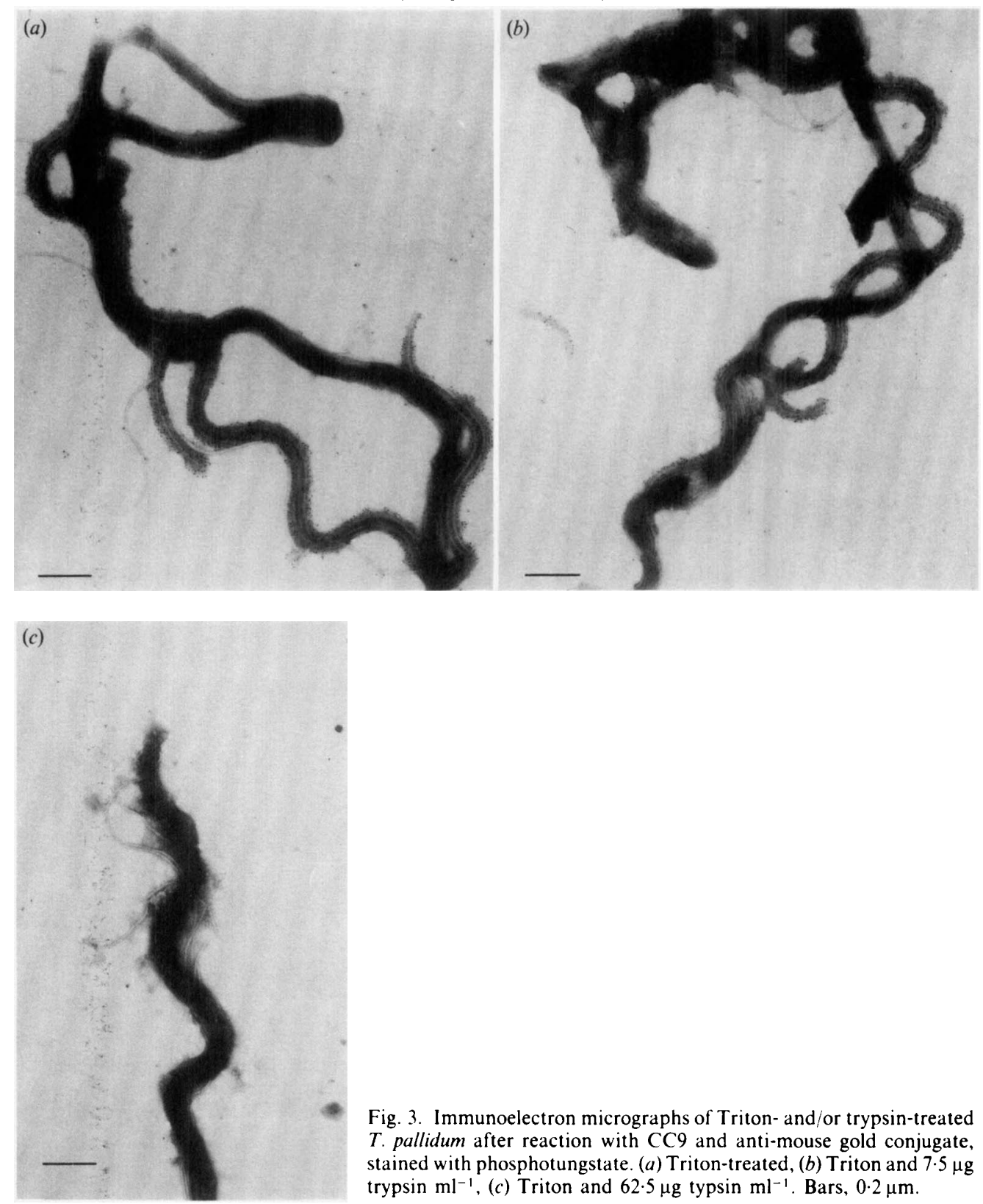

Fig. 3. Immunoelectron micrographs of Triton- and/or trypsin-treated $T$. pallidum after reaction with CC9 and anti-mouse gold conjugate, stained with phosphotungstate. (a) Triton-treated, (b) Triton and $7 \cdot 5 \mu \mathrm{g}$ trypsin $\mathrm{ml}^{-1}$, (c) Triton and $62.5 \mu \mathrm{g}$ typsin $\mathrm{ml}^{-1}$. Bars, $0 \cdot 2 \mu \mathrm{m}$.

individual filaments, antibody only appeared to bind to the thicker regions, suggesting that the antibody was recognizing the axial filament sheath structure. This observation was supported by the finding that thin, totally unsheathed filaments also failed to bind antibody (Fig. $2 b$ ). However a proportion of sheathed filaments also failed to react with CC9, even when antibody was present in saturating amounts, suggesting that antigenic heterogeneity was present even within the population of sheathed axial filaments.

\section{Incestigation of the axial filament sheath}

Low concentrations of trypsin $\left(7.5 \mu \mathrm{g} \mathrm{ml}^{-1}\right)$ in the presence of Triton had little effect on the morphology of axial filaments or on the reactivity of $\mathrm{CC} 9$ as assessed by immunogold electron microscopy (Fig. $3 a, b$ ) although SDS-PAGE analysis suggested that this treatment reduced the 


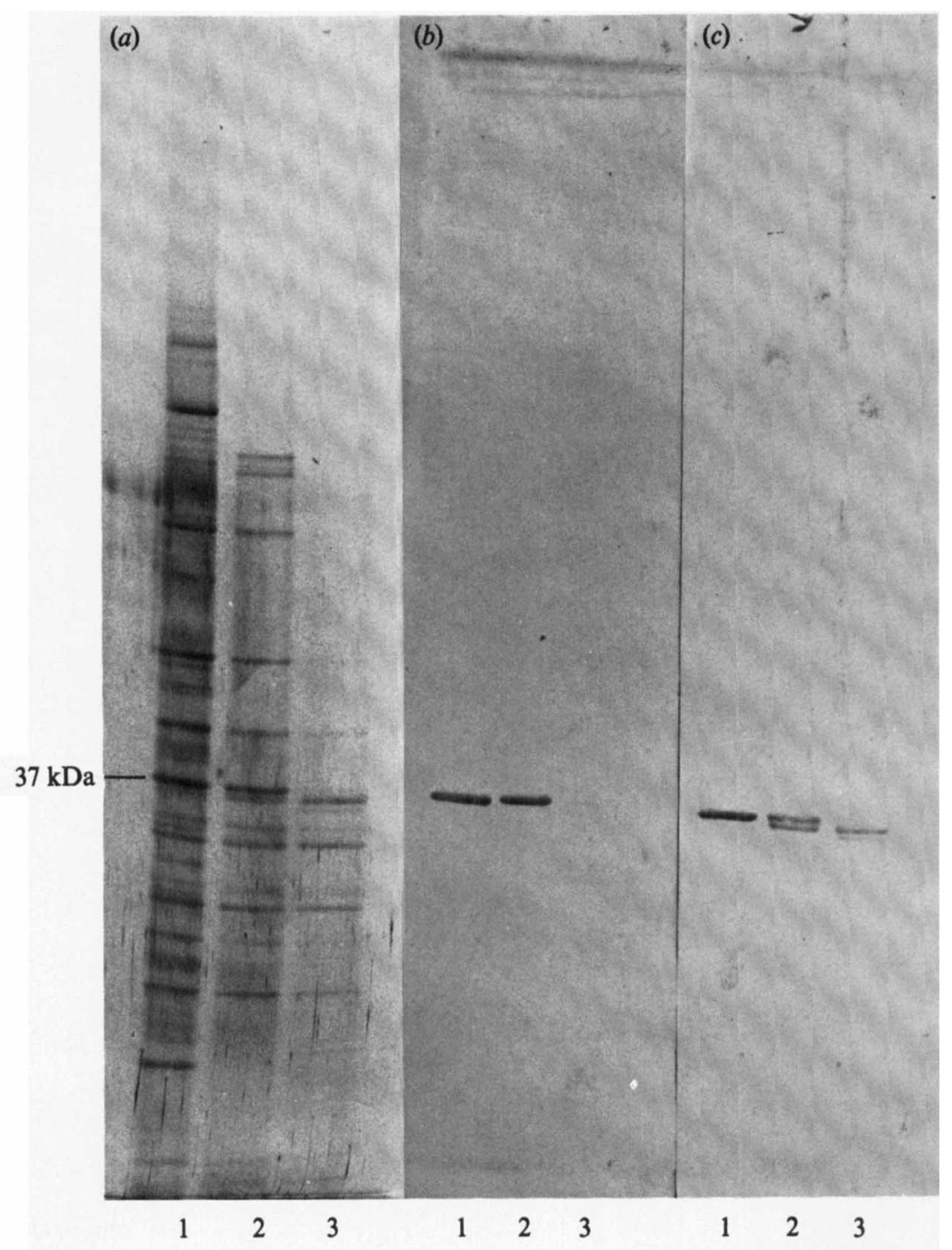

Fig. 4. Effect of trypsin on antibody binding to the $37 \mathrm{kDa}$ polypeptide. Triton-treated treponemes were incubated with buffer control (1), $7.5 \mu \mathrm{g}$ trypsin $\mathrm{ml}^{-1}$ (2) or $62.5 \mu \mathrm{g}$ trypsin $\mathrm{ml}^{-1}$ (3). (a) Silverstained gel; $(b)$ and $(c)$ Western blots reacted with monoclonal antibodies CC 9 and IB8, respectively.

apparent molecular mass of a proportion of the $37 \mathrm{kDa}$ band by about $1 \mathrm{kDa}$ (Fig. $4 \mathrm{a}$ ). Treatment with $62.5 \mu \mathrm{g}$ trypsin $\mathrm{ml}^{-1}$ completed this modification and produced a second novel polypeptide of approximately $35 \mathrm{kDa}$ molecular mass (Fig. $4 a$ ), suggesting that trypsin was cleaving the $37 \mathrm{kDa}$ polypeptide in a step-wise manner. Treatment with the higher concentration of trypsin also completely abrogated reactivity of CC9 with axial filaments by immunogold labelling (Fig. $3 c$ ). Neither concentration of trypsin appeared to have any major effect on the other axial filament polypeptides as assessed by SDS-PAGE. The morphology of these axial filaments was, however, markedly altered, with a loss of curvature and with variable effects on the surface morphology (Fig. 3c). Western blot analysis of these trypsin/Tritontreated preparations with the anti-37 $\mathrm{kDa}$ polypeptide monoclonal antibodies showed that trypsin was modifying the antigenicity of the axial filament sheath rather than completely removing it. Antibody $\mathrm{CC} 9$ did not react with the modified forms of the $37 \mathrm{kDa}$ polypeptide by Western blotting, suggesting that the determinant responsible for antibody binding had been 
(a)

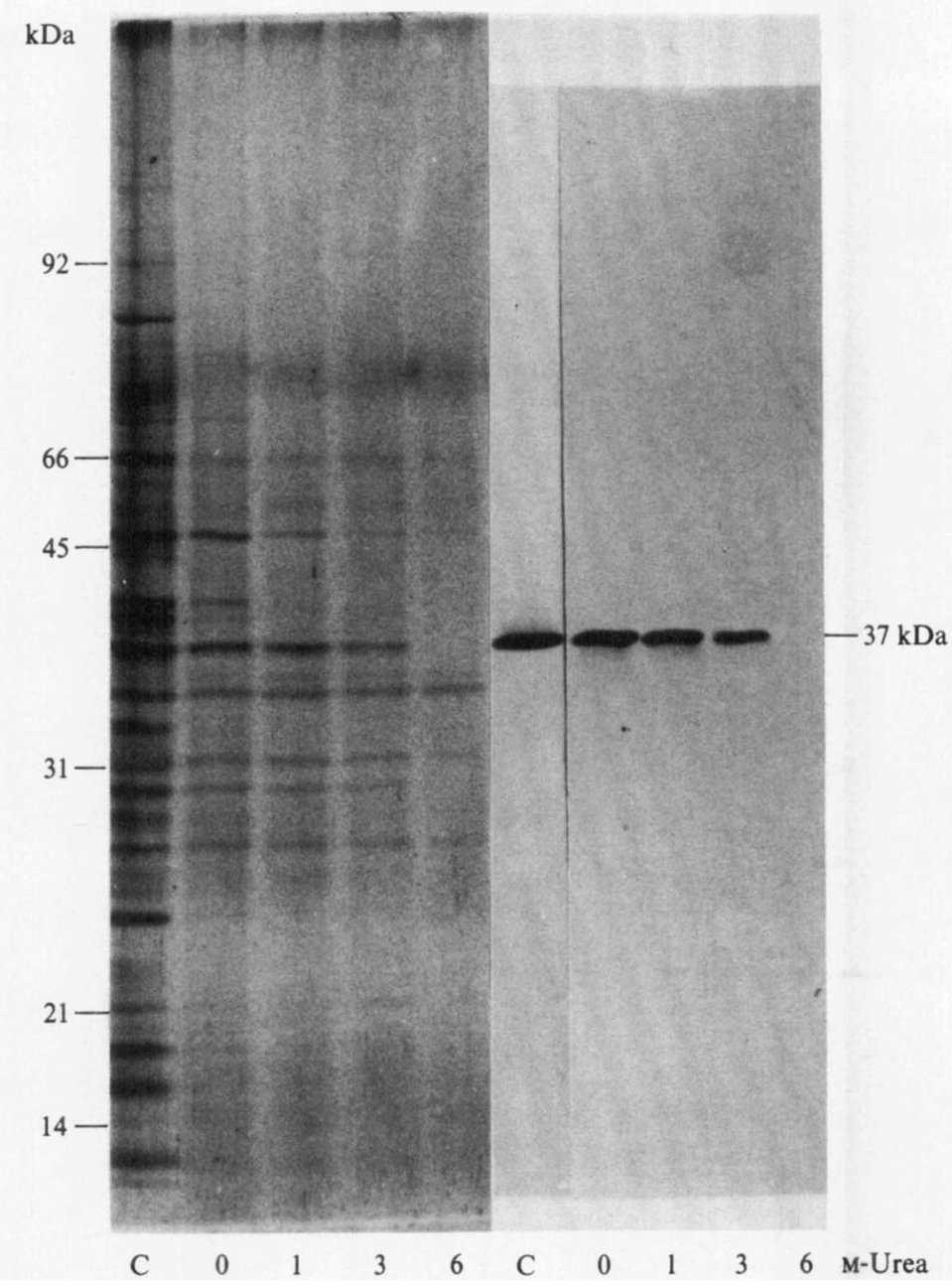

Fig. 5. Concentration-dependent solubilization of the $37 \mathrm{kDa}$ polypeptide by urea. Trypsin-treated $T$. pallidum were incubated with urea at the concentrations shown. (a) Silver-stained SDS-PAGE, $(b)$ Western blot with monoclonal antibody CC9. C, Control untreated cells.

removed (Fig. $4 b$ ). However, antibody IB8 reacted with both the native and modified forms of this polypeptide, suggesting that some of the antigenic determinants of the axial filament sheath were still present (Fig. $4 \mathrm{c}$ ). In contrast, treatment of treponemes with a low concentration of trypsin followed by treatment with urea appeared to totally remove the axial filament sheath (Fig. $2 c$ ). Increasing concentrations of urea effectively solubilized the sheath-associated $37 \mathrm{kDa}$ polypeptide and a second axial-filament-associated polypeptide of $31.5 \mathrm{kDa}$ (Fig. $5 a$ ). Complete removal of these polypeptides required both trypsin and urea treatment. Monoclonal antibody CC9 did not react with treponemes treated with a combination of trypsin and $6 \mathrm{M}$-urea either by Western blotting or immunogold electron microscopy (Figs $5 b$ and $2 c$ ). Monoclonal antibody IB8 and polyclonal anti- $T$. pallidum rabbit serum containing antibody to a range of $T$. pallidum antigens also failed to locate the $37 \mathrm{kDa}$ polypeptide by Western blotting after this treatment (Fig. 6). Monoclonal antibody JD11 (specific for the $31.5 \mathrm{kDa}$ polypeptide) also failed to react with $6 \mathrm{M}$-urea-treated treponemes by Western blotting (Fig. 6). Polyclonal mouse serum raised against these organisms failed to react with the $37 \mathrm{kDa}$ or the $31.5 \mathrm{kDa}$ axial filament 


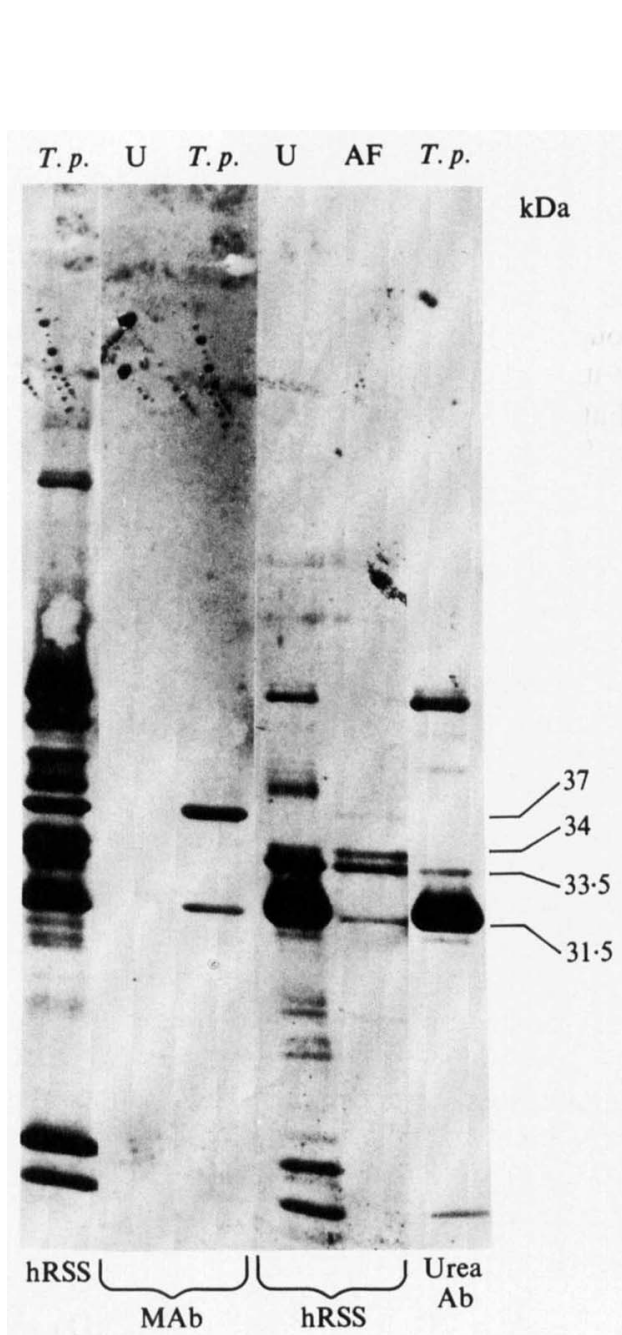

Fig. 6

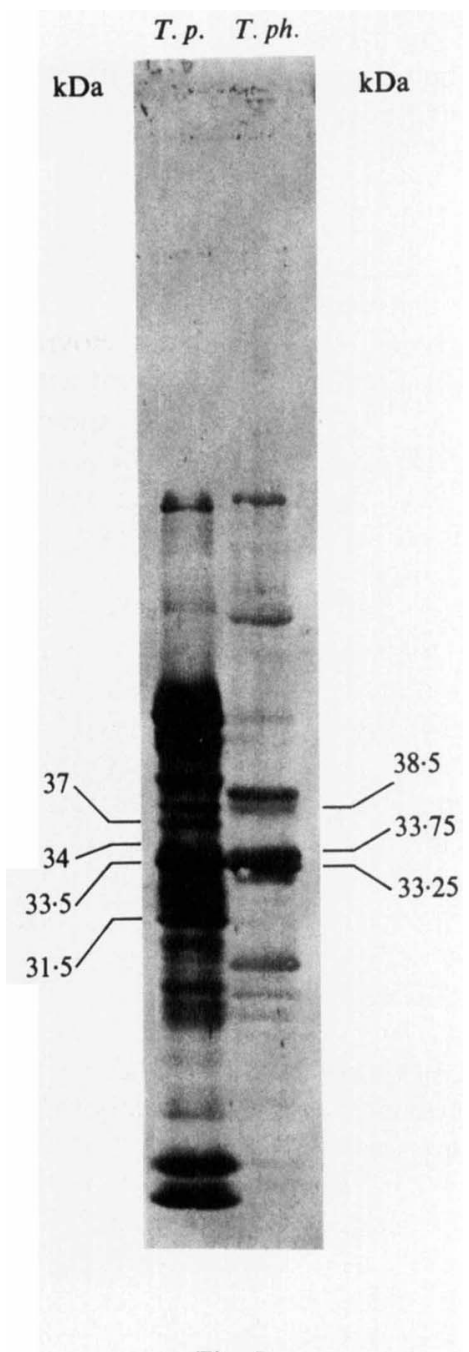

Fig. 7

Fig. 6. Western blots of whole $T$. pallidum $(T . p)$, urea-treated $T$. pallidum $(\mathrm{U})$ and purified axial filaments (AF) reacted with rabbit syphilitic serum (hRSS), a mixture of monoclonal antibodies CC9, IB8 and JD11 (Mab) or antibody to $6 \mathrm{M}$-urea-treated treponemes (urea Ab).

Fig. 7. Western blots of $T$. pallidum ( $T$. p) and $T$. phagedenis ( $T$. ph) with rabbit syphilitic serum (hRSS) showing partial antigenic cross-reactivity of axial filaments.

polypeptides of $T$. pallidum by Western blotting, but reacted strongly with the $33.5 \mathrm{kDa}$ and weakly with the $34 \mathrm{kDa}$ axial filament polypeptides (Fig. 6). When tested by immunogold electron microscopy, antibody in this serum reacted very weakly $(<1 \%$ of filaments labelled) with 'native' Triton-treated axial filaments but reacted very strongly ( $>99 \%$ of filaments labelled) with 6 M-urea-treated axial filaments (Fig. $2 d$ ).

\section{Antigenic cross-reactions between $T$. pallidum and $T$. phagedenis axial filaments}

Western blots of $T$. phagedenis with anti-T. pallidum rabbit serum are shown in Fig. 7. Anti- $T$. pallidum rabbit antibodies recognized the $38.5,33.75$ and $33.25 \mathrm{kDa}$ polypeptides in $T$. phagedenis but failed to detect the $31.25 \mathrm{kDa}$ polypeptide in this bacterium. Polyclonal anti- $T$. pallidum rabbit serum also labelled the axial filaments of $T$. phagedenis by immunogold electron 
microscopy. In addition serum raised against Triton/trypsin/urea-treated $T$. pallidum failed to label intact $T$. phagedenis axial filaments but strongly labelled axial filaments from which the sheath had been removed by a similar treatment (data not shown).

\section{DISCUSSION}

These observations confirm our suggestion that the $37 \mathrm{kDa}$ antigenic polypeptide of $T$. pallidum constitutes a component of the axial filament sheath (Bailey et al., 1987) and extend the morphological observations of Hovind-Hougen (1972). The sheath was completely removed from axial filaments by treatment with $6 \mathrm{M}$-urea as assessed by electron microscopy, and SDSPAGE and Western blotting showed that this treatment solubilized several treponemal polypeptides including the $37 \mathrm{kDa}$ antigen. In addition polyclonal mouse serum raised against urea-treated treponemes did not recognize the polypeptide by Western blotting and failed to react with sheathed axial filaments by immunoelectron microscopy. Trypsin at the relatively low concentrations used only partially digested the sheath, removing some antigenic determinants but leaving some others intact. The trypsin-sensitive determinants are presumably those exposed on the axial filament surface and accessible to enzyme activity. The trypsin-resistant determinants may be buried deeper in the sheath structure, possibly at the internal surface adjacent to the core. The observed lack of binding of antibody IB8 to intact axial filaments by immunoelectron microscopy supports this theory. The complete removal of the sheath required both trypsin and urea treatment. The effect of urea was concentration dependent, and trypsin treatment may have removed a proportion of the sheath, the remainder of which could then be solubilized by urea.

The observation that axial filaments released by Triton treatment sometimes completely or partially lacked a sheath suggests that a proportion of the sheath may be lost during manipulation of the treponemes and is in agreement with the earlier observations of HovindHougen (1972). This apparent fragility of the sheath may partially explain the variations in the relative proportions of the $37 \mathrm{kDa}$ polypeptide to other polypeptides in purified axial filament preparations observed in this laboratory (unpublished observations). The modified purification procedure for axial filaments described here involved shearing of the axial filaments in the presence of Triton and repeated washing in Sarkosyl. This procedure was designed to remove contaminating membrane material but it now seems apparent that this process could also contribute to the loss of a proportion of the axial filament sheath. It is also conceivable that these washing procedures could selectively remove different determinants from the sheath, e.g. surface-exposed determinants, contributing to the weak reactivity of the $37 \mathrm{kDa}$ antigen on Western blots (Fig. 6).

Triton/trypsin/urea-treated treponemes also failed to react with a monoclonal antibody against a second polypeptide of $31.5 \mathrm{kDa}$ present in purified axial filament preparations. It was impossible to confirm the location of this antigen by immunogold labelling as this antibody fails to react in this system but the urea solubility of this polypeptide suggests that it too may be associated with the sheath. The presence of a second axial filament sheath antigen may explain the observed failure of a proportion of sheathed axial filaments to react with anti-37 kDa monoclonal antibody by immunogold labelling and raises the possibility that antigenic heterogeneity may occur within the axial filament population. This could be due to variation in the $37 \mathrm{kDa}$ antigen structure or in its accessibility for antibody binding. Alternatively, some axial filaments may have sheaths containing other antigens including the $31.5 \mathrm{kDa}$ polypeptide. Development of other immunogold-reactive monoclonal antibodies to the $31.5 \mathrm{kDa}$ polypeptide would allow this hypothesis to be tested by the use of double-labelling experiments with gold probes of different sizes.

The axial filament core structure of $T$. pallidum appears to contain two polypeptides, a minor $34 \mathrm{kDa}$ polypeptide and a strongly antigenic major $33.5 \mathrm{kDa}$ component. Antisera to Triton/trypsin/urea-treated treponemes contain antibody primarily to the $33.5 \mathrm{kDa}$ polypeptide present in purified axial filament preparations and the strong immunogold reactivity of this serum with Triton/trypsin/urea-treated axial filaments supports the suggestion that this 
polypeptide is the major component of the axial filament core. The small amount of immunogold reactivity of this serum with axial filaments released by Triton treatment presumably reflects exposure of some core antigen in partially disrupted axial filaments as described above.

Our data also reinforce the reported partial cross-reactivity of axial filaments of $T$. pallidum and $T$. phagedenis reported by Hardy et al. (1975), since at least three of the four axial filament components in $T$. phagedenis react with polyclonal anti- $T$. pallidum serum. The most consistent reaction was detected against the doublet of core polypeptides of 33.25 and $33.75 \mathrm{kDa}$ in $T$. phagedenis whereas the reaction against the $38.5 \mathrm{kDa}$ polypeptide of $T$. phagedenis was variable and relatively weak. The variation in cross-reactivity of monoclonal antibodies to the $37 \mathrm{kDa}$ polypeptide of T. pallidum with $T$. phagedenis (Bailey et al., 1987) confirms the partial nature of the antigenic relatedness of these two polypeptides which may contribute to the weak and variable reaction observed. This cross-reaction does, however, support the suggestion that the $38.5 \mathrm{kDa}$ polypeptide in $T$. phagedenis represents a component of the axial filament sheath in this organism. This is consistent with the observation that a monoclonal antibody to a $39.8 \mathrm{kDa}$ axial-filament-associated polypeptide in $T$. phagedenis Kazan reacted on immunogold electron microscopy with the surface of the axial filament of this organism (Limberger \& Charon, 1986). However, in the present study antibody to the $31.5 \mathrm{kDa}$ antigen of $T$. pallidum did not react with $T$. phagedenis, emphasizing once again the partial nature of the antigenic relatedness of the axial filaments in the two species.

The variability in detectable cross-reactivity between different components of the axial filaments of these two bacteria has also contributed to the confusion in the literature as to the identity of their polypeptide components. Interest in the axial filament has been aroused because of the recognition of axial-filament-associated $37 \mathrm{kDa}$ antigen early in infection (Strandberg Pedersen et al., 1982; Penn et al., 1985) and its potential use as a reagent in diagnosis of syphilis. The use of $T$. pallidum axial filament antigen in diagnostic tests rather than that from $T$. phagedenis may produce a more specific and sensitive assay and such antigen could be produced using DNA recombinant technology. Attempts to identify the components of the axial filament components of $T$. pallidum, necessary for the identification of the correct recombinant phenotypes, solely by analysis of antigenic cross-reactivity may be misleading. Lukehart et al. (1982) failed to recognize the $37 \mathrm{kDa}$ axial filament antigen of $T$. pallidum based on interpretation of Western blotting data very similar to that described here and similar conclusions can be inferred from the work of Hinderson et al. (1985), although exact comparison is difficult because of the lack of molecular mass markers on the figures in that study.

These observations emphasize the need for a combined approach of biochemical and morphological analysis in understanding of the antigenic structure of $T$. pallidum.

Thanks are due to Mrs J. Gem and to Mr D. Ruffles for excellent technical support.

\section{REFERENCES}

Bailey, M. J., Cockayne, A. \& Penn, C. W. (1987). Production of murine monoclonal antibodies to the major axial filament polypeptide of Treponema pallidum. Journal of General Microbiology 133, (in the Press).

Bharrier, M. \& Allis, D. (1974). Purification and characterization of axial filaments from Treponema phagedenis biotype Reiterii (the Reiter treponeme). Journal of Bacteriology 120, 1434-1442.

Hardy, P. H., Fredericks, W. R. \& Nell, E. E. (1975). Isolation and antigenic characteristics of axial filaments from the Reiter treponeme. Infection and Immunity 11, 380-386.

Hindersson, P., Sand Petersen, C. \& Axelsen, N. H. (1985). Purified flagella from Treponema phagedenis biotype Reiter does not induce protective immunity against experimental syphilis in rabbits. Sexually Transmitted Diseases July-September, 124-127.
Hovind-Hougen, K. (1972). Further observations on the ultrastructure of Treponema pallidum Nichols. Acta pathologica et microbiologica scandinavica Section B 80, 297-304.

Hovind-Hougen, K. (1976). Determination by means of electron microscopy of morphological criteria for classification of some spirochetes, in particular treponemes. Acta pathologica et microbiologica scandinavica Section B, Supplement 255, 3-27.

Hovind-Hougen, K. (1983). Morphology. In Pathogenesis and Immunology of Treponemal Infection, pp. 3-28. Edited by R. F. Schell \& D. M. Musher. New York: Marcel Dekker.

LAEMMLI, U. K. (1970). Cleavage of structural proteins during the assembly of the head of bacteriophage T4. Nature, London 227, 680-682.

LIMBERGER, R. L. \& ChARON, N. W. (1986). Treponema phagedenis has at least two proteins residing together 
on its periplasmic flagella. Infection and Immunity 166, 105-112.

Lukehart, S. A., BaKer-Zander, S. A. \& Grubish, E. R. (1982). Identification of Treponema pallidum antigens: comparison with a non-pathogenic treponeme. Journal of Immunology 129, 833 - 838.

OAKLEY, B. L., KIRSCH, D. R. \& MORRIS, N. R. (1980). A simplified ultrasensitive silver stain for detecting proteins in polyacrylamide gels. Analytical Biochemistry 105, 361-363.

PenN, C. W. \& Rhodes, J. G. (1982). Surfaceassociated antigens of Treponema pallidum concealed by an inert outer layer. Immunology 46, 9-16.

Penn, C. W., Balley, M. J. \& Cockayne, A. (1985).
The axial filament antigen of Treponema pallidum. Immunology 54, 635-641.

Strandberg Pedersen, N., Sand Petersen, C. VejtorP, M. \& AXELSEN, N. H. (1982). Serodiagnosis of syphilis by an enzyme-linked immunosorbent assay for $\mathrm{IgG}$ antibodies against the Reiter treponeme flagellum. Scandinavian Journal of Immunology 15, 341-348.

Towbin, H., Staehlin, T. \& Gordon, G. (1979). Electrophoretic transfer of proteins from polyacrylamide gels to nitrocellulose sheets: procedure and some applications. Proceedings of the National Academy of Sciences of the United States of America 76, 4350-4354. 